\title{
Effect of plant and animal protein sources on the growth, gonadal maturity and proximate composition of Labeo rohita (Hamilton, 1822)
}

\author{
Neha Saxena ${ }^{1 *}$, Asha Dhawan², Meera D. Ansal', and Vikas Phulia ${ }^{1,2}$ \\ ${ }^{1}$ Central Institute of Fisheries Education, Mumbai-400 061(Maharastra),INDIA \\ ${ }^{2}$ Guru Angad Dev Veterinary and Animal Sciences University, Ludhiana- 141 004(Punjab),INDIA \\ *Corresponding author: E-mail: nehapnr@gmail.com
}

Received: February 3, 2015; Revised received: July 12, 2015; Accepted: August 4, 2015

\begin{abstract}
The aim of the present study was to evaluate the effect of plant and animal sources in the diet of Labeo rohita with an overall goal of gaining sustainable fish and egg production. Fishes with an initial weight of $310-323 \mathrm{~g}$ were fed with five different isocaloric $\left(3 \mathrm{Kcalg}^{-1}\right)$ diets viz. $\mathrm{D}_{1}$ ( control diet- $30 \%$ rice bran $+70 \%$ groundnut meal), $\mathrm{D}_{2}$ ( $30 \%$ rice bran $+50 \%$ groundnut meal $+20 \%$ fish meal), $\mathrm{D}_{3}$ (30\% rice bran $+50 \%$ groundnut meal $+20 \%$ mustard meal), $D_{4}\left(30 \%\right.$ rice bran $+30 \%$ groundnut meal $+20 \%$ mustard meal $+20 \%$ fish meal) and $D_{5}(30 \%$ rice bran + $30 \%$ soybean meal $+20 \%$ mustard meal $+20 \%$ fish meal) @ $3 \%$ of fish biomass for 270 days. Significantly higher weight gain and better gonadal maturity was recorded in fishes fed with diet containing fish meal than other. Among diets containing fish meal $\left(D_{2}, D_{4}, D_{5}\right)$, fish fed on diet $D_{2}$ resulted in higher somatic growth $(35.67,42.80,28.10$ and $18.48 \%$ higher net weight gain than $D_{1}, D_{3}, D_{4}$ and $D_{5}$, respectively) and better gonadal development (43.20, $50.08,22.59$ and $23.25 \%$ higher absolute fecundity than $D_{1}, D_{3}, D_{4}$ and $D_{5}$,respectively) in L. rohita. Hence, Our study revealed that for higher growth and better broodstock development, $L$. rohita may be fed on diet formulated with $30 \%$ rice bran, $50 \%$ groundnut meal and $20 \%$ fish meal.
\end{abstract}

Keywords: Diet, Growth, Labeo rohita, Proximate composition, Reproductive biology

\section{INTRODUCTION}

Fisheries sector plays an important role in the socio- economic development and nutritional security in developing countries like India. Out of the total 4.21 million tonnes $(\mathrm{mt})$ of inland fish production in India, about $3.37 \mathrm{mt}(80 \%)$ is being contributed by the aquaculture sector with an annual growth of about $6 \%$. Further, freshwater aquaculture sector contributes about $3.22 \mathrm{mt}$ to the total aquaculture production of the country with Indian major carps - (Cyprinidae family), constituting the major share (87\%) (Ayyappan 2009). Among cyprinids, Labeo rohita (rohu) is the most popular fish species cultivated in Indian subcontinent. Rohu is highly delicious and prestigious fish species among other Indian major carps (FAO, 2000).

Availability of quality seed in required quantity is a prerequisite for higher aquaculture productivity. Although induced breeding has been a major breakthrough in promoting fish seed production, but its success depends on the quantity and quality of eggs produced by the female. Hence, brood stock nutrition plays a vital role in the reproductive performance of fish which not only determines the number of eggs produced but also its viability in terms of egg size, hatchability and survival. An improvement in brood stock nutrition and feeding has shown improvement not only in egg and sperm quality, but also in seed production (Izquierdo et al.,
2001; Quintero et al., 2009).

Brood stock nutrition of carps is one of the most poorly researched areas in aquaculture. So far few studies have been made on brood stock nutrition of carps (Singh and Dhawan 1996; Khan et al., 2003, 2005; Anonymous 2006; Nandi et al., 2001, 2007). To a large extent, this may be due to the necessity of suitable indoor or outdoor culture facilities for maintaining large groups of adult fish and the consequent higher cost of running and conducting extended brood stock feeding trials (Varghese et al., 2009).

Keeping in view the economic importance of fish feeding, present study was undertaken to investigate the effect of five feeding regime with different ingredients on growth, gonadal maturation, fecundity, egg size and flesh composition of L. rohita over a period of 270 days.

\section{MATERIALS AND METHODS}

Feed and feeding trial: Five isocaloric diets (3Kcalg $\left.{ }^{-1}\right)$ with different plant and animal based ingredients viz. $\mathrm{D}_{1}\left(30 \%\right.$ rice bran and $70 \%$ groundnut meal), $\mathrm{D}_{2}$ (30\% rice bran ; 50\% groundnut meal and 20\% fish meal $), \mathrm{D}_{3}(30 \%$ rice bran ; 50\% groundnut meal and $20 \%$ mustard meal), $\mathrm{D}_{4}(30 \%$ rice bran ; 30\% groundnut meal; $20 \%$ mustard meal and $20 \%$ fish meal) and $\mathrm{D}_{5}$ (30\% rice bran ; 30\% soybean meal ; 20\% mustard meal and 20\% fish meal) were fed@3\% fish body 
weight $(\mathrm{FBW})$ throughout the culture period. Feed was provided in the form of dough and feeding was done at fixed corners of the pond every morning. The percent composition and cost are given in Tables 1 . The proximate analysis including crude protein (CP), ether extract (EE), crude fiber (CF), nitrogen free extract (NFE), neutral detergent fiber (NDF), acid detergent fiber (ADF), and ash on dry matter (DM) basis of different feed ingredients and prepared diets was done (Table 2) following the methods of AOAC (2000) in the Nutrition Laboratory, College of Fisheries, Guru Angad Dev Veterinary and Animal Sciences University (GADVASU), Ludhiana. Gross energy was calculated on the basis of gross energy values of crude protein, total carbohydrates (nitrogen free extract) and total lipids (ether extract) of respective diets in terms of kilocalories ${ }^{-1} \mathrm{~g}$ by using energy factor 5.65 for protein, 9.45 for fat and 4.10 for carbohydrate (Herpher et al., 1983).

Experimental tank and stocking of fish: The experiment was carried out in $80 \mathrm{~m}^{2}$ outdoor cemented ponds (0.008 ha). Five-inch thick layer of soil was spread at the bottom of each pond to hasten the decomposition process. The tube well water was used for initial filling of all the ponds and to compensate for losses (due to seepage and evaporation), as and when required. All the ponds were manured with cow dung@20,000 $\mathrm{kgha}^{-1} \mathrm{yr}^{-1}$. One fourth (40 kg per pond) of the manure was applied 15 days prior to the stocking of fish and rest in equal installments (10 kg per pond) on fortnight basis.

Male and female fishes were procured from fish farm of College of Fisheries, Guru Angad Dev Veterinary and Animal Sciences University, India. Each pond was stocked with yearlings of Indian major carp, rohu, $L$. rohita (Hamilton, 1822)@1,000 kg per ha (15 fish per pond). At the time of stocking, the average total body length and body weight of fish was $28-30 \mathrm{~cm}$ and 310 - 323 g respectively.

Water quality: Dissolved oxygen (DO), ammonia nitrogen, nitrite nitrogen, $\mathrm{pH}$ and alkalinity were recorded in all ponds at monthly interval following standard methods of estimation (APHA, 2012).

Growth and survival: Rate of survival in each treatment was determined by comparing the live fish recovered at the end of experiment with that of total fish stocked. The fish were weighed every month to calculate their mean body weight and the total biomass present in each tank. The fish were caught by netting. A random sample of 10 fish of each species from each pond was collected to record length and weight of fish. Then fish were weighed individually on a digital scale (accurate to $\pm 0.01 \mathrm{~g})$.

Growth of the fish were monitored in terms of Total length gain (TLG), net weight gain (NWG), percent total length gain ( $\%$ TLG), percent net weight gain ( $\%$ NWG), condition factor, for every treatment. The biological indices were calculated as:
TLG $=$ Average final body length $(\mathrm{cm})$ - Average initial body length $(\mathrm{cm})$

$\mathrm{NWG}=$ Average final body weight(g) - Average initial body weight $(\mathrm{g})$

$\%$ TLG $=$ Final body length $(\mathrm{cm})$-initial body length $(\mathrm{cm}) /$ initial body length $(\mathrm{cm}) \times 100$

$\% \mathrm{NWG}=$ Final body weight. $(\mathrm{g})$ - initial body wt. (g)/initial body wt (g) x 100

Condition factor $=$ Weight of fish / cube of ength $\times 100$

Gonadal maturity: Maturity of fish in terms of Gonado-Somatic Index (GSI), Hepato-Somatic Index (HSI), fecundity and ova diameter of L. rohita were carried out at the termination of the experiment. The fishes were selected and liver and ovary were dissected out. Ovarian sub-samples from different parts (anterior, middle and posterior) were collected for measuring the ova diameter with ocular micrometer. The ocular micrometer reading was converted into ' $\mathrm{mm}$ ' by calibrating the ocular micrometer with a stage micrometer.

The biological indices were calculated as:

Fecundity was estimated gravimetrically (Lagler, 1971).

\begin{tabular}{|c|c|c|}
\hline $\mathrm{HSI}=$ & Weight of Liver & X 100 \\
\hline & Weight of fish - Weight of liver & \\
\hline $\mathrm{GSI}=$ & Weight of gonads & X 100 \\
\hline
\end{tabular}

Biochemical analysis of flesh: Flesh samples from three specimens of $L$. rohita were collected from each experimental pond at the end of experiment and flesh quality in terms of total protein (Lowry et al.,1951), total lipids (Folch et al., 1957), carbohydrates (Dubois et al., 1956), moisture and ash contents were estimated using the standard methods (AOAC 2000).

Statistical analysis: All data are presented as mean \pm standard error. Data were statistically processed for one-way analysis of variance (ANOVA) and significance difference between two groups were determined by Duncan's multiple range test. The value $\mathrm{P}<0.05$ was used as the criterion for statistical significance. All the analysis was done by Statgraphics statistical package and SPSS.

\section{RESULTS}

Water quality: No significant differences in physico -chemical parameters (temperatures, $\mathrm{pH}$, dissolved oxygen, alkalinity, ammonical nitrogen, nitrate and nitrite) of water were found amongst five dietary treatments. Physico-chemical parameters of water varied in the range as temperature $\left(11.80\right.$ to $\left.34.10^{\circ} \mathrm{C}\right)$, $\mathrm{pH}$ (8.3 to 9.8), dissolved oxygen (8.0 to $11.75 \mathrm{mg} \mathrm{l}^{-1}$ ), phenolphthalein alkalinity (04 to $46 \mathrm{mg} \mathrm{CaCO}_{3} \mathrm{l}^{-1}$ ), methyl orange alkalinity ( 80 to $253 \mathrm{mg} \mathrm{CaCO}_{3} \mathrm{l}^{-1}$ ), total alkalinity (115 to $\left.279 \mathrm{mg} \mathrm{CaCO} \mathrm{l}^{-1}\right)$, ammonical - nitrogen $\left(0.071\right.$ to $\left.0.553 \mathrm{mg} \mathrm{l}^{-1}\right)$, nitrite - nitrogen $(0$ to $0.132 \mathrm{mg} \mathrm{l}^{-1}$ ) and were within optimum range for carp culture throughout the culture period. The data of all the month were pooled and listed in Table 3. 
Table 1. Percent composition and cost of different diets.

\begin{tabular}{llllll}
\hline Ingredients & \multicolumn{5}{c}{ Composition of experimental diets** } \\
\hline & $\mathbf{D}_{\mathbf{1}}^{* * *}$ & $\mathbf{D}_{\mathbf{2}}$ & $\mathbf{D}_{\mathbf{3}}$ & $\mathbf{D}_{\mathbf{4}}$ & $\mathbf{D}_{\mathbf{5}}$ \\
Rice bran* & 30 & 30 & 30 & 30 & 30 \\
Groundnut meal* $_{\text {Soybean meal* }}$ & 70 & 50 & 50 & 30 & - \\
Mustard meal* & - & - & - & - & 30 \\
Fish meal & - & - & 20 & 20 & 20 \\
Cost per diet & - & 20 & - & 14.01 & 20 \\
& 15.33 & 14.97 & 14.37 & $(0.22$ US \$) & $(0.24$ US \$) \\
\hline
\end{tabular}

*Solvent extracted, **All diets were supplemented with vitamin mineral mixture, salt and mustard oil @ 1.5\%, 0.5\% and 2\% respectively. $* * * \mathrm{D} 1$ is a control diet recommended by ICAR (Anonymous 2006). ****Cost calculated on the basis of prevailing market prices. Note: 1 Rupees is equal to $0.016 \$$

Table 2. Proximate composition (Dry Matter basis) and gross energy of different feed ingredients and prepared diets.

\begin{tabular}{ccccccccc}
\hline Ingredients/ diets & $\begin{array}{c}\mathbf{C P} \\
\mathbf{\%}\end{array}$ & $\begin{array}{c}\mathbf{E E} \\
\mathbf{\%}\end{array}$ & $\begin{array}{c}\mathbf{C F} \\
\mathbf{\%}\end{array}$ & $\begin{array}{c}\mathbf{A s h} \\
\mathbf{\%}\end{array}$ & $\begin{array}{c}\mathbf{N F E} \\
\mathbf{\%}\end{array}$ & $\begin{array}{c}\mathbf{N D F} \\
\mathbf{\%}\end{array}$ & $\begin{array}{c}\text { ADF } \\
\mathbf{\%}^{\mathbf{0}}\end{array}$ & $\begin{array}{c}\mathbf{G E} \\
\left(\mathbf{K c a l g}^{-\mathbf{1}}\right)\end{array}$ \\
\hline Rice bran* & 11.90 & 1.95 & 15.05 & 11.10 & 60.00 & 53.10 & 29.05 & 3.31 \\
Groundnut meal* & 33.40 & 1.07 & 19.90 & 8.57 & 37.06 & 30.20 & 34.40 & 3.50 \\
Soybean meal* & 51.00 & 1.55 & 7.65 & 6.60 & 33.20 & 16.70 & 13.70 & 4.38 \\
Mustard meal* & 35.10 & 2.40 & 10.80 & 7.79 & 43.91 & 30.00 & 21.70 & 4.01 \\
Fish meal & 33.70 & 3.50 & 8.20 & 8.70 & 45.90 & 8.60 & 6.60 & 4.11 \\
$\mathrm{D}_{1}$ (Control diet) & 26.95 & 1.33 & 18.08 & 9.32 & 44.32 & 35.26 & 22.90 & 3.46 \\
$\mathrm{D}_{2}$ & 27.33 & 1.90 & 15.74 & 9.35 & 45.68 & 35.26 & 18.00 & 3.59 \\
$\mathrm{D}_{3}$ & 27.29 & 1.59 & 16.26 & 9.16 & 45.70 & 36.60 & 23.80 & 3.56 \\
$\mathrm{D}_{4}$ & 27.35 & 2.10 & 13.92 & 9.19 & 47.44 & 31.50 & 18.00 & 3.68 \\
$\mathrm{D}_{5}$ & 31.03 & 2.30 & 10.24 & 8.69 & 47.83 & 31.10 & 18.11 & 3.93 \\
\hline
\end{tabular}

*Solvent extracted, CP- crude protein, EE- ether extract, CF- crude fiber, NFE- nitrogen free extract, NDF- neutral detergent fiber, ADF- acid detergent fiber (ADF), GE- gross energy

Table 3. Water quality parameters recorded in cemented tanks containing L. rohita during the culture period.

\begin{tabular}{|c|c|c|c|c|c|}
\hline Parameter & $\mathbf{D}_{1}$ & $\mathbf{D}_{2}$ & $\mathbf{D}_{3}$ & $\mathbf{D}_{4}$ & $\mathbf{D}_{5}$ \\
\hline Temperature $\left({ }^{\circ} \mathrm{C}\right)$ & $22.34^{\mathrm{a}} \pm 2.59$ & $21.68^{\mathrm{a}} \pm 2.53$ & $22.18^{\mathrm{a}} \pm 2.58$ & $21.81^{\mathrm{a}} \pm 2.55$ & $22.13^{\mathrm{a}} \pm 2.59$ \\
\hline $\mathrm{pH}$ & $9.29^{\mathrm{a}} \pm 0.12$ & $9.34^{\mathrm{a}} \pm 0.12$ & $9.08^{\mathrm{a}} \pm 0.17$ & $8.98^{\mathrm{a}} \pm 0.14$ & $9.29^{\mathrm{a}} \pm 0.12$ \\
\hline Dissolved oxygen $\left(\mathrm{mg} \mathrm{l}^{-1}\right)$ & $10.12^{\mathrm{a}} \pm 0.37$ & $10.15^{\mathrm{a}} \pm 0.22$ & $10.20^{\mathrm{a}} \pm 0.37$ & $9.9^{\mathrm{a}} \pm 0.38$ & $10.02^{\mathrm{a}} \pm 0.33$ \\
\hline Total Alkalinty (mg $\mathrm{CaCO}_{3} \mathrm{l}^{-}$ & $\begin{array}{c}191.38^{\mathrm{a}} \pm \\
17.28\end{array}$ & $\begin{array}{l}192.89^{\mathrm{a}} \pm \\
16.18\end{array}$ & $\begin{array}{c}186.78^{\mathrm{a}} \pm \\
14.98\end{array}$ & $\begin{array}{c}210.67^{\mathrm{a}} \pm \\
19.39\end{array}$ & $\begin{array}{l}198.00^{\mathrm{a}} \pm \\
16.36\end{array}$ \\
\hline $\begin{array}{l}\text { Phenophthaline Alkalinity } \\
\left(\mathrm{mg} \mathrm{CaCO}_{3} 1^{-1}\right)\end{array}$ & $23.11^{\mathrm{a}} \pm 3.00$ & $26.11^{\mathrm{a}} \pm 1.53$ & $24.66^{\mathrm{a}} \pm 3.18$ & $22.11^{\mathrm{a}} \pm 2.70$ & $27.16^{\mathrm{a}} \pm 2.78$ \\
\hline Methyl Orange Alkalinity & $168.22^{\mathrm{a}} \pm$ & $166.78^{\mathrm{a}}$ & $162.11^{\mathrm{a}} \pm$ & $188.56^{\mathrm{a}} \pm$ & $170.78^{\mathrm{a}}$ \\
\hline$\left(\mathrm{mg} \mathrm{CaCO} \mathrm{Cl}_{3}^{-1}\right)$ & 18.42 & \pm 17.45 & 16.21 & 20.31 & \pm 17.34 \\
\hline Ammonical-nitrogen $\left(\mathrm{mg} \mathrm{l}^{-1}\right)$ & $0.286^{\mathrm{a}} \pm 0.03$ & $0.275^{\mathrm{a}} \pm 0.04$ & $0.216^{\mathrm{a}} \pm 0.03$ & $0.242^{\mathrm{a}} \pm 0.04$ & $0.254^{\mathrm{a}} \pm 0.04$ \\
\hline Nitrite-Nitrogen $\left(\mathrm{mg} \mathrm{l}^{-1}\right)$ & $0.031^{\mathrm{a}} \pm 0.01$ & $0.024^{\mathrm{a}} \pm 0.01$ & $0.024^{\mathrm{a}} \pm 0.01$ & $0.047^{\mathrm{a}} \pm 0.01$ & $0.055^{\mathrm{a}} \pm 0.01$ \\
\hline Nitrate-Nitrogen $\left(\mathrm{mg} \mathrm{l}^{-1}\right)$ & $4.51^{\mathrm{a}} \pm 0.24$ & $4.56^{\mathrm{a}} \pm 0.23$ & $4.45^{\mathrm{a}} \pm 0.27$ & $4.21^{\mathrm{a}} \pm 0.18$ & $4.50^{\mathrm{a}} \pm 0.16$ \\
\hline Orthophosphate $\left(\mathrm{mg} \mathrm{l}^{-1}\right)$ & $0.082^{\mathrm{a}} \pm 0.02$ & $0.116^{\mathrm{a}} \pm 0.02$ & $0.108^{\mathrm{a}} \pm 0.02$ & $0.109^{\mathrm{a}} \pm 0.02$ & $0.078^{\mathrm{a}} \pm 0.02$ \\
\hline
\end{tabular}

Data presented as Mean \pm Standard error $(n=6)$. Figures with same superscript letters in rows are not significantly different from each other at $\mathrm{p}>0.05$.

Growth and survival: The growth parameters for $L$. rohita yearling in the different treatments $\left(D_{1}-D_{5}\right)$ in terms of mean body weight gain, \%weight gain, mean length gain, \% length gain, SGR, survival (\%) were calculated and are shown in Table 4 . The results of
ANOVA obtained from the study indicated a varied growth rate under different treatments. $\mathrm{D}_{2}$ showed significantly higher $(\mathrm{p}<0.05)$ growth compared to all other treatments. Net weight gain was maximum $(463.31 \mathrm{~g})$ in $\mathrm{D}_{2}$ and minimum $(261.07 \mathrm{~g})$ in $\mathrm{D}_{3}$. The 
Table 4. Growth parameters of the L. rohta fed with different dietary treatments.

\begin{tabular}{cccccc}
\hline Parameters & $\mathbf{D}_{\mathbf{1}}$ & $\mathbf{D}_{\mathbf{2}}$ & $\mathbf{D}_{\mathbf{3}}$ & $\mathbf{D}_{\mathbf{4}}$ & $\mathbf{D}_{\mathbf{5}}$ \\
\hline $\begin{array}{c}\text { Mean initial } \\
\text { body length(cm) } \\
\text { Mean final body } \\
\text { length (cm) }\end{array}$ & $29.82^{\mathrm{a}} \pm 0.28$ & $29.48^{\mathrm{a}} \pm 0.01$ & $29.64^{\mathrm{a}} \pm 0.05$ & $29.81^{\mathrm{a}} \pm 0.08$ & $29.73^{\mathrm{a}} \pm 0.01$ \\
TLG & $35.17^{\mathrm{b}} \pm 0.48$ & $37.05^{\mathrm{a}} \pm 0.08$ & $34.62^{\mathrm{b}} \pm 0.68$ & $34.41^{\mathrm{b}} \pm 0.05$ & $35.81^{\mathrm{ab}} \pm 0.15$ \\
$\begin{array}{c}\text { \% TLG } \\
\text { Mean initial }\end{array}$ & 5.35 & 7.57 & 4.98 & 4.60 & 6.08 \\
body weight(g) & $323.76^{\mathrm{a}} \pm 9.37$ & $313.89^{\mathrm{a}} \pm 2.40$ & $311.46^{\mathrm{a}} \pm 4.69$ & $311.29^{\mathrm{a}} \pm 6.37$ & $310.50^{\mathrm{a}} \pm 0.47$ \\
Mean final body & $631.15^{\mathrm{bc}} \pm 30.07$ & $777.20^{\mathrm{a}} \pm 11.95$ & $572.53^{\mathrm{c}} \pm 27.18$ & $641.65^{\mathrm{bc}} \pm 13.94$ & $684.12^{\mathrm{b}} \pm 4.54$ \\
weight(g) & 307.39 & 463.31 & 261.07 & 330.36 & 373.62 \\
NWG & 94.94 & 147.60 & 83.82 & 106.12 & 120.32 \\
$\begin{array}{c}\text { \% NWG } \\
\text { \% NG over }\end{array}$ & -- & 55.46 & -11.71 & 11.77 & 26.73 \\
control & 0.26 & 0.36 & 0.24 & 0.29 & 0.32 \\
$\begin{array}{c}\text { SGR } \\
\text { Condition Factor }\end{array}$ & 1.45 & 1.53 & 1.38 & 1.57 & 1.50 \\
$\begin{array}{c}\text { (k) } \\
\text { Survival rate (\%) }\end{array}$ & $100 \pm 00$ & $100 \pm 00$ & $100 \pm 00$ & $100 \pm 00$ & $100 \pm 00$ \\
\hline
\end{tabular}

Data presented as Mean \pm Standard Error $(n=6)$. Figures with same superscript letters in rows are not significantly different from each other at $p>0.05$.

Table 5. Gonadal maturity status of $L$. rohita in different treatments at the termination of experiment.

\begin{tabular}{|c|c|c|c|c|c|}
\hline Parameters & $\mathbf{D}_{1}$ & $\mathbf{D}_{2}$ & $\mathbf{D}_{3}$ & $\mathbf{D}_{4}$ & $\mathbf{D}_{5}$ \\
\hline $\begin{array}{c}\text { Average weight of } \\
\text { fish }(\mathrm{g})\end{array}$ & $629^{\mathrm{b}} \pm 14.08$ & $859^{a} \pm 8.16$ & $562^{b} \pm 12.80$ & $659^{\mathrm{b}} \pm 34.82$ & $674^{\mathrm{b}} \pm 9.72$ \\
\hline $\begin{array}{l}\text { Average weight of } \\
\text { ovary }(\mathrm{g})\end{array}$ & $115^{b c} \pm 14.98$ & $156^{\mathrm{a}} \pm 19.22$ & $98^{\mathrm{c}} \pm 10.30$ & $143^{\mathrm{ab}} \pm 9.43$ & $136^{\mathrm{abc}} \pm 12.24$ \\
\hline $\begin{array}{l}\text { Hepato-somatic } \\
\text { Index }\end{array}$ & $0.43^{\mathrm{c}} \pm 0.01$ & $0.45^{\mathrm{c}} \pm 0.02$ & $0.39^{c} \pm 0.01$ & $1.05^{\mathrm{a}} \pm 0.11$ & $0.74^{b} \pm 0.01$ \\
\hline $\begin{array}{c}\text { Gonado-somatic } \\
\text { index }\end{array}$ & $22.40^{\mathrm{a}} \pm 0.39$ & $22.29^{\mathrm{a}} \pm 2.24$ & $20.47^{\mathrm{a}} \pm 2.87$ & $27.85^{\mathrm{a}} \pm 2.19$ & $25.40^{\mathrm{a}} \pm 1.75$ \\
\hline $\begin{array}{l}\text { Absolute Fecundity } \\
\text { (per ovary) }\end{array}$ & $\begin{array}{c}127305^{\mathrm{c}} \pm \\
13617\end{array}$ & $\begin{array}{l}224162^{\mathrm{a}} \pm \\
44636\end{array}$ & $111894^{\mathrm{c}} \pm 5773$ & $\begin{array}{c}173509^{\mathrm{b}} \pm \\
17320\end{array}$ & $\begin{array}{c}172040^{\mathrm{b}} \pm \\
17349\end{array}$ \\
\hline $\begin{array}{l}\text { Relative Fecundity } \\
\text { (per g of ovary) }\end{array}$ & $1107^{\mathrm{c}} \pm 15.41$ & $1512^{\mathrm{a}} \pm 24.37$ & $1153^{\mathrm{c}} \pm 17.81$ & $1213^{\mathrm{b}} \pm 21.08$ & $1265^{\mathrm{b}} \pm 27.92$ \\
\hline Ova diameter (mm) & $0.64^{\mathrm{b}} \pm 0.01$ & $0.84^{\mathrm{a}} \pm 0.02$ & $0.67^{\mathrm{b}} \pm 0.01$ & $0.86^{\mathrm{a}} \pm 0.03$ & $0.84^{\mathrm{a}} \pm 0.02$ \\
\hline
\end{tabular}

Data presented as Mean \pm Standard Error $(n=6)$. Figures with same superscript letters in rows are not significantly different from each other at $\mathrm{p}>0.05$.

Table 6. Proximate composition (\%) of flesh (on wet weight basis) of L. rohita in different treatments at the termination of experi-

\begin{tabular}{cccccc}
\hline Parameters & $\mathbf{D}_{\mathbf{1}}$ & $\mathbf{D}_{\mathbf{2}}$ & $\mathbf{D}_{\mathbf{3}}$ & $\mathbf{D}_{\mathbf{4}}$ & $\mathbf{D}_{\mathbf{5}}$ \\
\hline Total Protein & $10.86^{\mathrm{b}} \pm 0.24$ & $12.37^{\mathrm{a}} \pm 0.29$ & $11.81^{\mathrm{b}} \pm 0.26$ & $12.66^{\mathrm{a}} \pm 0.27$ & $13.02^{\mathrm{a}} \pm 0.27$ \\
Total Lipid & $1.29^{\mathrm{b}} \pm 0.10$ & $1.49^{\mathrm{b}} \pm 0.06$ & $1.21^{\mathrm{b}} \pm 0.05$ & $1.56^{\mathrm{b}} \pm 0.06$ & $2.45^{\mathrm{a}} \pm 0.37$ \\
Total Carbohydrate & $3.43^{\mathrm{a}} \pm 0.15$ & $3.15^{\mathrm{a}} \pm 0.11$ & $3.93^{\mathrm{a}} \pm 0.22$ & $3.59^{\mathrm{a}} \pm 0.24$ & $3.46^{\mathrm{a}} \pm 0.37$ \\
Moisture & $80.82^{\mathrm{a}} \pm 0.31$ & $80.14^{\mathrm{a}} \pm 0.98$ & $80.28^{\mathrm{a}} \pm 0.98$ & $79.64^{\mathrm{a}} \pm 1.15$ & $79.92^{\mathrm{a}} \pm 0.77$ \\
Ash & $1.25^{\mathrm{a}} \pm 0.05$ & $1.40^{\mathrm{a}} \pm 0.12$ & $1.36^{\mathrm{a}} \pm 0.07$ & $1.46^{\mathrm{a}} \pm 0.45$ & $1.50^{\mathrm{a}} \pm 0.91$ \\
\hline
\end{tabular}

Data presented as Mean \pm Standard Error $(n=6)$. Figures with same superscript letters in rows are not significantly different from each other at $\mathrm{p}>0.05$.

$\%$ Net weight gain was maximum $(147.60 \%)$ in $\mathrm{D}_{2}$ and minimum $(83.82 \%)$ in $\mathrm{D}_{3}$. As compared to control $\left(D_{1}\right), \%$ NWG was $55.46,11.77$ and $26.73 \%$ higher in
$\mathrm{D}_{2}, \mathrm{D}_{4}$ and $\mathrm{D}_{5}$, respectively and $11.71 \%$ lower in $\mathrm{D}_{3}$. Fishes reared with different feeds attained mean total length from 29.80 to $35.17 \mathrm{~cm}$ in $\mathrm{D}_{1}, 29.48$ to 37.05 
$\mathrm{cm}$ in $\mathrm{D}_{2}, 29.64$ to $34.62 \mathrm{~cm}$ in $\mathrm{D}_{3}, 29.81$ to $34.41 \mathrm{~cm}$ in $\mathrm{D}_{4}$ and 29.73 to $35.81 \mathrm{~cm}$ in $\mathrm{D}_{5}$. Total length gain was maximum $(7.57 \mathrm{~cm})$ in $\mathrm{D}_{2}$ and minimum $(4.60$ $\mathrm{cm})$ in $\mathrm{D}_{4}$ and the differences amongst different treatments were significant $(\mathrm{P}<0.05)$. The $\%$ TLG was maximum $(25.67 \%)$ in $\mathrm{D}_{2}$ and minimum $(15.43 \%)$ in $\mathrm{D}_{4}$. SGR was maximum (0.36) in $\mathrm{D}_{2}$ and minimum (0.24) in $\mathrm{D}_{3}$ Result indicates that diet containing fish meal leads to better growth than others.

Reproductive status: At the end of the experiment, the reproductive status of fish was studied in term of GSI, HSI, fecundity and egg diameter. Reproductive status of $L$. rohita maintained on five different diets are shown in Table 5. No significant difference $(p>0.05)$ was found in GSI between the different dietary treatments and the value was 22.40 in $\mathrm{D}_{1}, 22.29$ in $\mathrm{D}_{2}$, 20.47 in $D_{3}, 27.85$ in $D_{4}$ and 25.40 in $D_{5}$. Absolute fecundity in rohu is very variable as shown in Table 5. Absolute fecundity was significantly higher $(\mathrm{p}<0.05)$ in the $\mathrm{D}_{2}$ fed group while it was lowest in diets which were deficient in fish meal. In the study, the average absolute fecundity varied from $1,11,894$ to $2,24,162$ in five treatments and differed significantly $(\mathrm{p}<0.05)$. Ova diameter of the fish ranged from 0.64 to $0.86 \mathrm{~mm}$ at the end of culture period with maximum $(0.86 \mathrm{~mm})$ in $\mathrm{D}_{4}$ and minimum $(0.64 \mathrm{~mm})$ in $\mathrm{D}_{1}$. From the Table 5 , it is clear that diets containing fish meal differ significantly in terms of egg size than without fish meal.

Proximate composition of body: Whole body proximate composition is shown in Table 6. Fishes fed different experimental diets exhibited no significant differences $(p>0.05)$ in terms of total carbohydrate, ash and moisture composition, however, whole body protein and lipid content varied significantly $(\mathrm{p}<0.05)$. The highest protein content was observed in group fed with diet containing fish meal however lowest was observed in control $\left(\mathrm{D}_{1}\right)$. Highest total lipid was recorded in $\mathrm{D}_{5}(2.45 \%)$ and minimum in $\mathrm{D}_{3}(1.21 \%)$.

\section{DISCUSSION}

The results of the present study clearly indicated better health and reproductive condition of the group fed with diets containing fish meal. To obtain high yield in term of growth and quality of fish is the main goal of aqua culturist. The fish growth attributed as an increase in overall length and weight of fish under feeding regime. The net weight gain of fishes was significantly higher $(p<0.05)$ in groups fed with fish meal $\left(D_{2}, D_{4}, D_{5}\right)$ than control $\left(\mathrm{D}_{1}\right)$. It can be attributed to increased feed acceptability and palatability and hence less wastage of feed which ultimately led to increased growth and a commensurate conversion into flesh (Ovie and Ovie, 2007). In addition, fish meal also is rich in polyunsaturated fatty acids (PUFA) and has balanced amino acid profile. Among diets having fish meal $\left(\mathrm{D}_{2}, \mathrm{D}_{4}, \mathrm{D}_{5}\right)$, fish fed on diet $\mathrm{D}_{2}$ resulted in higher somatic growth (35.67, $42.80,28.10$ and $18.48 \%$ higher net weight gain than
$\mathrm{D}_{1}, \mathrm{D}_{3}, \mathrm{D}_{4}$ and $\mathrm{D}_{5}$, respectively) than others. Low growth and feed intake of fish fed with soybean meal and mustard meal might be due to the presence of anti nutritional factors (Refstie et al., 1998; Francis et al., 2001; Peres et al., 2003), low protein digestibility (Refstie et al., 1998) or deficiency of the essential amino acids (Chong et al., 2003; Tantikitti et al., 2005). Lin and Luo (2011) reported a decrease in SGR and growth of tilapia, Oreochromis niloticus with an increase in dietary soybean meal. Similar results have been reported in L. rohita (Khan et al., 2003; Saeed et al., 2005; Ahmed et al., 2012), Barbodes altus (Elangovan and Shim, 2000), red tilapia (Moharram and Raky, 2007). However, Abid and Ahmed (2009) has reported contrasting results and found diet containing soybean and sunflower meal attained good growth than diet containing fish meal. Silva-carrillo (2012) reported that up to $20 \%$ replacement of fishmeal with soybean meal did not impart any significant difference on growth of spotted rose snapper. Similar results were reported in marine species such Japanese flounder, Korean rockfish, olive flounder and Senegalese sole (Choi et al., 2004; Kikuchi 1999; Lim et al., 2004; Cabral et al., 2011).

One way to improve gamete quality and viable larvae production is improving broodfish nutrition and feeding (Izquierdo et al., 2001.) A variety of plant protein sources are substituted for fish meal to increase sustainability and reduced cost. However, gonadal maturity in this study was increased by inclusion of fishmeal compared to all plant protein sources. Fecundity and egg diameter were significantly higher $(p<0.05)$ for fishes fed with fishmeal containing diets $\left(D_{2}, D_{4}\right.$ and $\left.D_{5}\right)$ than group fed without fishmeal $\left(D_{1}\right.$ and $\left.D_{3}\right)$. This result may be attributed to the presence of good amount of phospholipids in fishmeal (Hertrampf and Pieded pascual 2000) which plays an important role during ovarian development. In addition, it is a rich source of PUFA which plays a significant role in regulation of gonadptropin as well as vitellogenesis. However, among diets containing fish meal, $\mathrm{D}_{2}$ showed significant higher $(\mathrm{p}<0.05)$ absolute fecundity than others $(43.20$, $50.08,22.59$ and $23.25 \%$ higher absolute fecundity than $D_{1}, D_{3}, D_{4}$ and $D_{5}$, respectively). It could be due to the presence of anti nutritional factors (Peres et al., 2003), low n-3 PUFA with low phosphorus avaibility (Robaina et al., 1995), deficiency of methionine and lysine (Pandey et al., 2009) and high level of isoflavonoid phytoestrogen (Dixon, 2004) in soybean meal. Similar results were obtained in gilthead seabream (Zohar et al., 1995), rainbow trout (Pereira et al., 1998), tilapia (Cumaranatunga and Thabrew, 1989), sharpsnout seabream (Hernandez et al., 2007), channel catfish (Sink et al., 2010) and gold fish (Bagheri et al., 2013). This indicated that inclusion of at least one animal protein source i.e. fish meal improves not only somatic growth but also the reproductive capacity of $L$. rohita. In the present study, the flesh protein content of the 
fish increases with the increase in the dietary protein level irrespective of the dietary ingredients with maximum in $\mathrm{D}_{5}$. Wang et al. (2006) also reported that fish body protein is not affected by the type of dietary ingredient in fish diets. The results are in agreement with the findings of Al- Hafedh (1999) who reported increased protein content of the fish body with the increase in dietary protein level in tilapia, O. niloticus. Similarly, Muchlisin et al., (2006) reported increase in body protein content of Mystus nemurus with the increase in dietary protein level from $30 \%$ to $45 \%$. However, Zakeri et al., (2009) reported that the body protein content in Acanthopagrus latus was not significantly affected by the dietary protein and lipid level. Increase in carcass/muscle lipid with increasing dietary lipid has been reported for most of the species (Vergara et al., 1996;Gangadhar et al., 1997; Regost et al ., 2001). Ai et al. (2004) also reported that carcass lipid content of juvenile Japanese seabass, Labrax japonicas, positively correlated with the dietary lipid level and ash content however, inversely correlated with moisture content. In contrast, Regost et al. (2001) found no significant difference in whole body moisture and ash content of fish body in fishes fed with different diets.

\section{Conclusion}

The results exhibited that the inclusion of fish meal in the diet of L. rohita significantly increases the somatic growth, gonadal development and body protein of fish but do not significantly change the carbohydrate, moisture and ash of fish. Baseline data generated from the present study would be useful in developing future cost effective balanced broodstock diets of $L$. rohita.

\section{ACKNOWLEDGEMENTS}

We sincerely thank to Vice Chancellor, Guru Angad Dev Veterinary and Animal Sciences University (GADVASU), Ludhiana for providing necessary facilities for conducting this study.

\section{REFERENCES}

Abid M. and Ahmed M.S. (2009). Growth response of Labeo rohita fingerlings fed with different feeding regimes under intensive rearing. The Journal of Animal \& Plant Sciences, 19(1): 45-49

Ahmed M.S., Shafiq K and Kiani M.S. (2012). Growth performance of major carp, Labeo rohita fingerlings on commercial feeds. The Journal of Animal \& Plant Sciences, 22(1): 93-96

Ai Q, Mai K, Li H, Zhang C, Zhang L, Duan Q, Tan B, Xu W, Ma H, Zhang W and Liufu Z. (2004). Effects of dietary protein to energy ratios on growth and body composition of juvenile Japanese seabass, Labrax japonicas. Aquaculture, 230: 507-16.

Anonymous. (2006). Carp Breeding and Seed Production. Hand Book of Fisheries and Aquaculture. Pp 248-264. Indian Council of Agricultural Research. New Delhi.

AOAC. (2000). Official methods of analysis. $17^{\text {th }}$ Ed. AOAC International, Gaithersburg, MD.
Al Hafedh Y.S, Siddiqui A.Q. and Saiady M.Y. (1999). Effects of dietary protein levels on gonad maturation, size and age at first maturity, fecundity and growth of Nile tilapia. Aquaculture International, 7: 319-32.

APHA (2012). Standard methods for the examination of water and waste water. 22th edition., American Public Health Association, Washington D.C.

Ayyappan S. (2009). Towards blue Revolution. In: Souvenir National Workshop on Advances in Aquaculture and Fisheries Perspectives, Prospects and challenges. ILDEX India 2009 Aquaculture, New Delhi. pp1-5

Bagheri T, Imanpoor M.R, Jafari V and Bennetau-Pelissero C. (2013). Reproductive impairment and endocrine disruption in goldfish by feeding diets containing soyabean meal. Animal Reproduction Science, 139:136-144

Cabral, E.M., Bacelar, M., Batista, S., Castro-Cunha, M., Ozório, R.O.A., Valente, L.M.P. (2011). Replacement of fishmeal by increasing levels of plant protein blends in diets for Senegalese sole (Solea senegalensis) juveniles. Aquaculture 322-323, 74-81.

Choi, S.M., Wang, X., Park, G.J., Lim, S.R., Kim, K.W., Bai, S.C., Sin, I.S. (2004). Dietary dehulled soybeanmeal as a replacement for fish meal in fingerling and growing olive flounder Paralichthys olivaceus (Temminck et Schlegel). Aquaculture Research 35, 410-418.

Chong, A., Hashim, R., Ali, A. (2003). Assessment of soybean meal in diets for discus (Symphysodon aequifasciata HECKEL) farming through a fish meal replacement study. Aquaculture Research 34, 913-922.

Cumaranatunga, P.R.T. and H. Thabrew. (1989). Effects of legume (Vigna catiang) substituted diets on the ovarian development of Oreochromis niloticus. Proceedings of the Third International Symposium on Feeding and Nutrition in Fish, 28 August-1 September. Toba, Japan Translation Centre, Tokyo, pp. 333-344

Dixon R.A. (2004). Phytoestrogens. Annual Review of Plant Biology 55:225-261

Dubois M, Gilles K.A, Hamiton J.K., Robert P.A. and Smith F. (1956). Colorimetric method for the determination of sugars and related substances. Analytical Chemist 28: 350-56.

Elangovan, A., Shim, K..F. (2000). The influence of replacing fish meal partially in the diet with soybean meal on growth and body composition of juvenile tin foil barb (Barbodes altus). Aquaculture 189, 133-144.

FAO. (2000). Fishery Statistics (Aquaculture Production). Food and Agriculture Organization of the United Nations, Rome, 90(2): 22-131

Folch J., Lees M. and Sloane - Stanley G.H. (1957). A simple method for the isolation and purification of total lipids from animal tissues. Journal of Biological Chemistry 226: 497-509.

Francis G., Makkar H..P.S. and Becker K. (2001). Antinutritional factors present in plant-derived alternate fish feed ingradients and their effects in fish. Aquaculture 199:197-227

Gangadhar B., nandeesha M.C., Verghese T.J. and Keshavnath P. (1997). Effects of varying protein and lipid levels on the growth of rohu Labeo rohita. Asian Fisheries Society. 10: $139-42$.

Hernandez M.D., Jover M.M. and Garcia B.G. (2007). Effect of partial replacement of fish meal by soybean meal in sharpsnout seabream (Diplodus puntazzo) diet. Aquaculture 263:159-167

Herpher B., Liao I.C., Cheng S.H. and Hsieh C.S. (1983). Food utilization by red tilapia- affects of diet composition, 
feeding level and temperature on utilization efficiencies for maintenance and growth. Aquaculture 32: 255-75.

Hertrampf J.W. and Piedad-Pascual F. (2000). Handbook on ingredients for aquaculture feeds. Kluwer Academic Publishers. London.

Izquierdo M.S., Fernandez-Palacios H. and Tacon A.G.J.. (2001). Effect of broodstock nutrition on reproductive performance of fish. Aquaculture 197: 25-42.

Khan, M.A., A.K. Jafri, N.K. Chadha and N. Usmani. (2003). Growth and body composition of rohu (Labeo rohita) fed diets containing oilseed meals: partial or total replacement of fish meal with soybean meal. Aquaculture Nutrition. 9(6): 391-396.

Khan, M.A., Jafri A.K. and Chadha N.K. (2005). Effects of varying dietary protein levels on growth, reproductive performance, body and egg composition of rohu, Labeo rohita(Hamilton). Aquaculture Nutrition 11: 11-17.

Kikuchi, K. (1999). Use of defatted soybean meal as a substitute for fish meal in diets of Japanese flounder (Paralichthys olivaceus). Aquaculture 179, 3-11.

Lagler K.F. (1971). Freshwater Fishery Biology. W.C. Brown Publishers, Lowa, USA.

Lim, S.R., Choi, S.M., Wang, X.J., Kim, K.W., Shin, I.S., Min, T.S., Bai, S.C. (2004). Effects of dehulled soybean meal as a fish meal replacer in diets for fingerling and growing Korean rockfish (Sebastes schlegeli). Aquaculture 231, 457-468.

Lin, S. and Luo, L. (2011). Effects of different levels of soybean meal inclusion in replacement for fish meal on growth, digestive enzymes and transaminases activity in practical diets for juvenile tilapia, Oreochromis niloticus X $O$. aureus. Animal Feed Science and Technology doi: 10.1016/j.anifeedsci.2011.03.012,

Lowry O.H., Rosenbrough N.J., Farr A.L. and Randall R.J. (1951). Protein measurement with folin phenol reagent. Journal of Biological Chemistry 193: 265-75.

Moharram S.G. and Raky F.A. (2007). Effect of varying dietary protein sources on growth and spawning performance and gonad maturation of red tilapia reared in sea water. Pakistan Journal of Biological Sciences. 10 (21): 3742-3751

Muchlisin Z.A., Hashim, R. and Chong, A.S.C. (2006). Influence of dietary protein levels on growth and egg quality in broodstock female Bagrid catfish (Mystus nemurus Cuv. \& Val.). Aquaculture Research 37: 416-18.

Nandi S., Chattopadhyay D.N., Verma J.P., Sarkar S.K. and Mukhopadhaya P.K. (2001). Effect of dietary supplementation of fatty acids and vitamins on the breeding performance of the carp Catla catla. Reproductive Nutrition Development 41:365-75.

Nandi S., Routray P., Gupta S.D., RathS C., Dasgupta S., Meher P.K. and Mukhopadhyay P.K. (2007). Reproductive performance of carp, Catla catla (Ham.), reared on a formulated diet with PUFA supplementation. Journal of Applied Ichthyology 23(6): 684-91.

Ovie S. and Ovie S. (2007). The effect of replacing fish meal with $10 \%$ of groundnut cake in the diets of $H$. longlifilis on its growth, food conversion and survival. Journal of Applied Sciences and Environmental Science 11: 87-90.

Pandey A.K., Arvindakshan P.K. and Singh B.N. (2009). Early maturation in broodstocks of Indian major carps maintained on semi-balanced diet supplemented with lysine and methionine. Recent Advances in Hormonal Physiology of fish and shellfish Reproduction Pp. 175-82.
Pereira J., Reis-Henriques M.A., Sanchez J.L. and Costa J. M. (1998). Effect of protein source on the reproductive performance of female rainbow trout, Oncorhynchus mykiss (Walbaum). Aquaculture Research 29(10):751-760

Peres H., Lim C. and Klesius P.H. (2003). Nutritional value of heat treated soybean meal for channel catfish, Ictalurus punctatus. Aquaculture 225: 67-82.

Quintero H.E., Hutson A., Chaimongkol A., Davis A., Dunham R., Abebe A. (2009). Effects of varying dietary protein levels and feeding frequencies on condition and reproductive performance of channel catfish to produce hybrid catfish. Journal of the World Aquaculture Society 40:601-15.

Refstie S., Trond S. and Roem A.J. (1998). Feed consumption and conversion in atlantic salmon (Salmo salar) fed diets with fish meal, extracted soybean meal or soybean meal with reduced content of oligosaccharides, trypsin inhibitor, lectins and soya antigens. Aquaculture 162: 301-12.

Regost C., Arzel1 J., Cardinal M., Robin J., Laroche M. and Kaushik S.J. (2001). Dietary lipid level, hepatic lipogenesis and flesh quality in turbot (Psetta maxima). Aquaculture 193 (3-4) : 291-09.

Robaina L., Izquierdo M.S., Moyano F.J., Socorro J., Vergara J.M., Montero D. and Fernandez-Palacios H. (1995). Soybean and lupin seed meals as protein sources in diets for gilthead seabream (Sparus aurata): nutrition and histological implications. Aquaculture 130:219-33.

Saeed M., M. Salim and U. Noreen (2005). Study of the growth performance and feed conversion ration of $\mathrm{La}$ beo rohita fingerlings, fed on soybean meal, blood meal corn gluten 62\%. Pakistan Veterinary Journal 25 3:121 $-126$.

Silva-Carrillo Y., Hernández C., Hardy RW., González -Rodríguez B. and Castillo-Vargasmachuca S. (2012). The effect of substituting fish meal with soybean meal on growth, feed efficiency, body composition and blood chemistry in juvenile spotted rose snapper Lutjanus guttatus (Steindachner, 1869). Aquaculture 364-365: 180-185.

Sink T.D., Lochmann R.T., Pohlenz C., Buentello A. and Gatlin D. (2010). Effects of dietary protein source and protein- lipid source interaction on channel catfish (Ictalurus punctatus) egg biochemical composition, egg production and quality and fry hatching percentage and performance. Aquaculture 298: 251-259

Singh R. and Dhawan A. (1996). Effect of formulated diets on the growth and ovarian maturation in common carp Cyprinus carpio communis Linn. Indian Jornal of Fisheries 43: 349-53.

Tantikitti, C., Sangpong, W., Chiavareesajja, S. (2005). Effects of defatted soybean protein levels on growth performance and nitrogen and phosphorus excretion in Asian seabass (Lates calcarifer). Aquaculture 248, 41-50.

Varghese, B., Paulraj, R., Gopakumar, G., \& Chakraborty, K. (2009). Dietary influence on the egg production and larval viability in True Sebae Clownfish Amphiprion sebae Bleeker 1853. Asian Fisheries Science 22(1): 7-20.

Vergara J.M., Robaina L., Izquierdo M.S. and De la Higuela M. (1996). Protein sparing effect of lipids in diets for fingerling of gilthead sea bream. Marine Mammal Science 62: 624-28.

Wang C., Harris W.S., Chung M., Lichtenstein A.H., Balk 
E.M., Kupelnick B., Jordan H.S. and Lau J. (2006). n-3 fatty acids from fish or fish-oil supplements, but not $\alpha$-linolenic acid, benefit cardiovascular disease outcomes in primary- and secondary-prevention studies: a systematic review. American Journal of Clinical Nutrition 48: 5-17.

Zakeri M., Marammazi J.G., Kochanian P., Savari A., Yavari V. and Haghi M. (2009). Effects of protein and lipid concentrations in broodstock diets on growth, spawning performance and egg quality of yellowfin sea bream (Acanthopagrus latus). Aquaculture 295 : 99-105

Zohar Y., Harel M., Hassin S. and Tandler A. (1995). Gilthead seabeam. In : Bromage N.R., Robert R.J. (eds.), Broodstock management and egg and larval Quality. Pp 424. Cambridge University press, Cambridge. 